\title{
Physiological and histological effects of broccoli on lead acetate induced hepatotoxicity in young male albino rats
}

\author{
S.M. Mohammed ${ }^{1}$ M.N. Ibrahim² and M.O. Ahmed ${ }^{1}$ \\ ${ }^{1}$ Biology Department, College of Science, University of Sulaimani, Sulaimani, \\ ${ }^{2}$ Biology Department, College of Science, University of Kirkuk, Kirkuk, Iraq, email: drmajidanoori@gmail.com
}

(Received April 18, 2018; Accepted July 1, 2018)

\begin{abstract}
The aim of this study was to investigate the ameliorative effect of Broccoli against lead acetate ( $\mathrm{PbA}$ ) hepatotoxicity by some physiological and histological indicators. The results showed that intraperitoneal (I.P.) injection by $12 \mathrm{mg} / \mathrm{kg}$ body weight of lead acetate once a week for 8 weeks led to an increase in the activity of Glutamate pyruvate transaminase (GPT), Glutamate oxaloacetate transaminase (GOT), Alkaline phosphatase (ALP), Acid phosphatase (ACP), Total serum protein (TP) and Total serum bilirubin (TSB). Liver's histological sections of lead acetate injected rats showed infiltration of inflammatory cells with sinusoid dilation, necrosis, and apoptosis of Kupffer cells. Broccoli has an ameliorative effect, that the physiological parameters and histological examination have been showed an improvement. In conclusion, lead acetate produces hepatic disorder and the potential use of Broccoli as a source of natural antioxidants or nutraceuticals protects against lead acetate hepatic toxicity.
\end{abstract}

Keywords: Broccoli, Lead, Liver function, Liver histology, Histopathology Available online at http://www.vetmedmosul.com

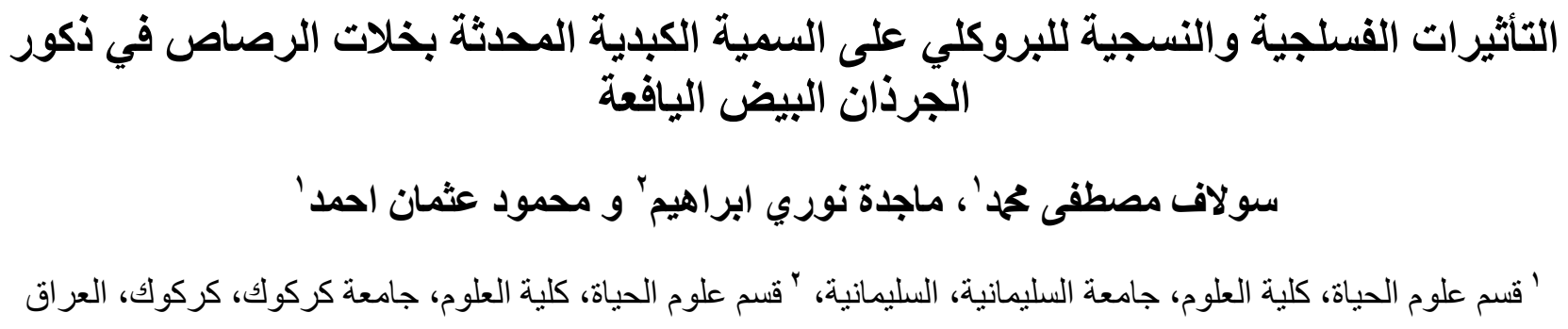

تهدف الدر اسة الحالية إلى معرفة التأثير العلاجي للبروكلي على السمية الكبدية المستحدثة بخلات الرصاص PbA في ذكور الجرذان

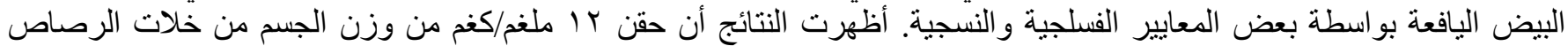

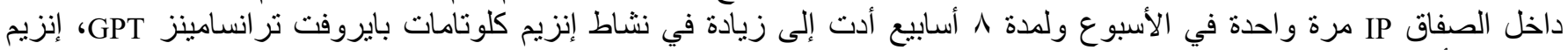

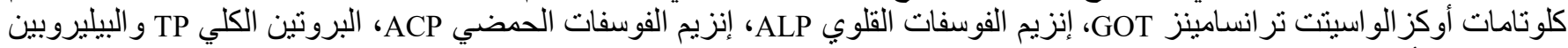

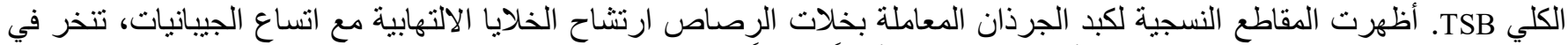

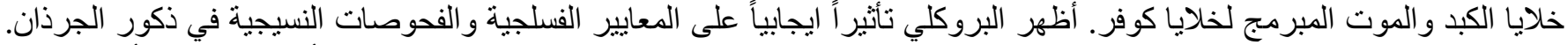

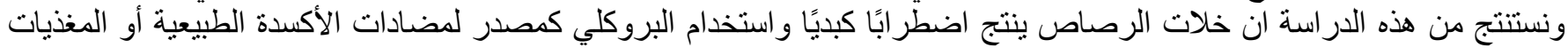
يحمي الكبد من سمية خلات الرصاص.

\section{Introduction}

The use of heavy metals is intimately connected to human history, lead is a toxic heavy metal with global concern, there are large number of studies on its effect and another studies about the root of its toxicity, on the other hand how human being protect or cure themselves of this toxic heavy metal for example in recent study on the effect 
of lead on children they found that lead accumulated in liver, kidney and bone by blood circulation and they tried to find solution in order to protect school children from lead toxicity (1). Lead $(\mathrm{Pb})$ has been shown to have a multisystem effect like the nervous, hematopoietic, skeletal, renal, circulatory and endocrine systems (2-4). Long-term exposure to $\mathrm{Pb}$ may also result in a nephropathy or renal adenocarcinoma, neuromuscular weakness, behavioral, and neurochemical alterations $(5,6)$. These serious affecting of lead can occur through a derangement of the antioxidant enzymes and neurotransmitter balance $(7,8)$. Lead has affinity for proteins and capacity to simulate iron $(\mathrm{Fe})$ and calcium channels (9). The increase in intracellular calcium together with the increase in reactive oxygen species, can trigger apoptosis through the cytochrome $\mathrm{C}$ release and a fall in the mitochondrial potential $(9,10)$. Due to the increased using of lead in industry and agriculture we have to develop special nutritional strategies in order to overcome the negative effects of lead toxicity. Dietary strategies are advantageous, as nutritional ingredients can easily and affordably be added to the daily diet (11).

Epidemiological data indicate that frequent fruit and vegetable consumption cause reduction in morbidity and mortality from several dangerous diseases $(12,13)$ and this is due to their high content in polyphenols, vitamins, minerals and other bioactive molecules. Reports on the increasing role and usefulness of medicinal plant products in maintenance and optimization of health have led to research on the efficacy of these medicinal plants/nutrient products' effects on the amelioration of the metal-induced toxicity (14). These plant products are reported to affect the bioavailability, transport, and toxico-dynamics of this metal in the tissue. Broccoli is an edible plant which is classified under the italic cultivar group of species Brassica oleracea. It is belonging to family Brassicaceae. Broccoli has large green flower head which is arranged like a tree like structure branching out from a thick edible stalk and has very promising future (15). Broccoli also helps in attenuate of many diseases like arthritis, kidney diseases, diabetes, and skin disorders. Various researches done earlier showed that it contains sulforaphane which helps in treating many disease (16). Up- to-date study have demonstrated that eating raw Broccoli has been associated with improvement of fertility of male rats and decreasing lead poisoning effects (17). Also, other studies recommended using the whole vegetable instead of using isolated bioactive chemicals to demonstrated the effects of possible interactions of different molecules within of the food matrix on several chronic disease (18). Raw green Broccoli is chemically defined as a complex mixture of very biological active structures like carotenoids, phenols, vitamins C, E, $\mathrm{Fe}$ and glucosinolates (19-21) and used as a source of antioxidant and anti-inflammatory effects (22).
The aim of the study is to evaluating the ability of raw Broccoli that has rank among the top 20 foods in regards to ANDI score (Aggregate Nutrient Density Index), which measures vitamin, mineral and phytonutrient content in relation to caloric content (19) to reduce the hepatotoxic effects of $\mathrm{Pb}$ in male rats by estimation levels of important liver enzymes, total serum protein, and bilirubin, with microscopic examination of liver.

\section{Material and methods}

\section{Experimental animals}

Twenty-eight young male rats (160-180) g aged 8-10 weeks were randomly housed in plastic cages. The cages were cleaned and sterilized weekly with $70 \%$ ethanol. Each cage was embedded with wooden shelve and maintained under standard laboratory condition for at least two weeks before initiation of the experiments (23).

\section{Broccoli}

Dry Broccoli (Brassica oleracea) was grinding with using a grinder (WAHL James MARTIN) into a fine powder. The powder used for the Preparation of Standard diet containing $12 \%$ Broccoli.

\section{Experimental Design}

Twenty-eight young male albino rats, weight $160-180 \mathrm{~g}$ were used for this study. Rats were housed in temperaturecontrolled rooms at $25^{\circ} \mathrm{C}$ with constant humidity $40-70 \%$, and a $12 \mathrm{~h} \mathrm{light/dark}$ cycle. All animals were treated in accordance with the principles of laboratory animal care. The rats that included in this study were divided into four groups of seven rats each as follow. A: the animals served as the control group, rats were kept on normal diet and pure distilled water. B: the animals were fed with $12 \%$ Broccoli diet and water ad libitum for eight weeks. C: the animals were injected I.P.with $12 \mathrm{mg} / \mathrm{Kg}$ body weight of lead acetate, ones each a week for eight weeks (24). D: the animals were injected I.P with $12 \mathrm{mg} / \mathrm{Kg}$ body weight of lead acetate ones each a week for eight weeks respectively, and were given $12 \%$ Broccoli diet and water ad libitum during the period of experiment. At the end of each experiment, animals have been fasted for $12 \mathrm{hrs}$ and sacrificed after chloroform anesthesia. Blood samples have been taken by heart puncture and allowed to clot. Serum was separated by centrifuging at $2500 \mathrm{rpm}$ for $15 \mathrm{~min}$ by using Centrifuge and micropipette then serum was stored in the deep freeze at $-45 \mathrm{C}^{\circ}$.

\section{Biochemical study}

The activity of GPT, GOT, ALP, ACP, TP and TSB of all groups have been determined by enzymatic colorimetric methods using commercial laboratory kit purchased from (BIOLABO-FRANCE) and by using Cobas instrument (25). 


\section{Histopathology}

After the animals have been sacrificed, the livers were removed and immediately fixed in $10 \%$ formalin, treated with conventional grade of alcohol and xylene, embedded in paraffin, and sectioned at $4-6 \mu$ thickness. The sections were stained with Hematoxylin and Eosin (H\&E) stains for studying the histopathological changes (26).

\section{Statistical Analysis}

Analysis of data was performed by using SPSS version 15 , results were expressed as mean \pm SE statistical differences were determined by Duncan Post Hoc test for multiple comparisons after ANOVA.

\section{Results and discusssion}

Occupational and environmental exposure to lead, a toxic metal pollutant, is of global concern. Lead has been found in drinking water. It can come from plumbing and fixture that may be made of lead (27). Absorbed lead is stored in soft tissues mainly the liver tissues (28). The liver is the first organ exposed to internally absorbed nutrients via the portal vein (29). Four enzymes in addition to the levels of total proteins and bilirubin were used to evaluate the function of the liver as shown in table 1, and proved by microscopical examination of histological structure of liver as shown in figures 1-4. Table 1 has been shown that there are no significant differences between group A the control and group B the one that fed on $12 \%$ Broccoli.

Table 1: Effect of Broccoli and Lead acetate on serum Glutamate pyruvate transaminase (GPT), Glutamate oxaloacetate transaminase (GOT), Alkaline phosphatase (ALP), Acid phosphatase (ACP), Total serum bilirubin (TSB), and Total serum P (TP)

\begin{tabular}{lcccc}
\hline \multirow{2}{*}{ Parameters } & \multicolumn{4}{c}{ Mean \pm SE } \\
\cline { 2 - 5 } & $\mathrm{A}$ & $\mathrm{B}$ & $\mathrm{C}$ & $\mathrm{D}$ \\
\hline GPT (IU) & $122.4 \pm 0.19^{\mathrm{a}}$ & $122.1 \pm 0.24^{\mathrm{a}}$ & $144.4 \pm 0.15^{\mathrm{c}}$ & $125.9 \pm 0.08^{\mathrm{b}}$ \\
GOT (IU) & $41.8 \pm 0.1^{\mathrm{a}}$ & $40.7 \pm 0.1^{\mathrm{a}}$ & $62.1 \pm 0.14^{\mathrm{c}}$ & $45.8 \pm 0.1^{\mathrm{b}}$ \\
ALP (IU) & $221.9 \pm 0.1^{\mathrm{a}}$ & $221.8 \pm 0.3^{\mathrm{a}}$ & $251.9 \pm 0.12^{\mathrm{c}}$ & $226.6 \pm 0.15^{\mathrm{b}}$ \\
ACP (IU) & $4.2 \pm 0.03^{\mathrm{a}}$ & $4.2 \pm 0.04^{\mathrm{a}}$ & $6.7 \pm 0.04^{\mathrm{c}}$ & $4.6 \pm 0.04^{\mathrm{b}}$ \\
TSB (mg/dL) & $0.2 \pm 0.002^{\mathrm{b}}$ & $0.2 \pm 0.003^{\mathrm{b}}$ & $0.1 \pm 0.003^{\mathrm{a}}$ & $0.21 \pm 0.004^{\mathrm{b}}$ \\
TP (mg/dL) & $6.8 \pm 0.04^{\mathrm{c}}$ & $6.8 \pm 0.03^{\mathrm{c}}$ & $0.2 \pm 0.002^{\mathrm{a}}$ & $4.5 \pm 0.05^{\mathrm{b}}$ \\
\hline
\end{tabular}

Standard Error (SE) of Mean $\mathrm{P}<0.05$ significant, similar small letters refers to nonsignificant differences while the different letters refers to significant differences among the groups.

The histological analysis of rats livers that represented in figure 1 and 2 of group A, as well as liver of group B respectively, showed normal histological structure of active functioning cells, the light microscopic images of sections of liver tissue of both A and B groups showing cords of hepatocytes $(\mathrm{HC})$ central veins $(\mathrm{Cv})$, blood sinusoids(BS), Kupffer cells $(\mathrm{Kc})$, and portal area note bile duct $(\mathrm{Bd})$ Figure (1).

While Lead acetate treated group as shown in table 1 reveled significant increasing of the liver function parameters GPT, GOT, ALK and ACP and serum bilirubin while significantly decreasing in the levels of TP compared by control and Broccoli feed groups due to the damage in liver cell of $\mathrm{Pb}^{+2}$ intoxicated animals. These results could be expected to occur associating with pathology involving necrosis $(\mathrm{N})$ and apoptosis Kupffer cells (A), infiltration of inflammatory cells (Inc), sinusoid dilation (Bs) of the liver as shown in figure 3 .

In such cases the cellular enzymes escape to the plasma from the injured hepatic cells as these enzymes are present in large quantities in the liver. These observations are in agreement with previous study which reported that lead has hepatotoxic effect (30). Alteration the levels of GPT, GOT, ALP and ACP are of value indicating the existence of liver diseases, as this enzyme is present in large quantities in the liver and this in agreement with the study of (31). One of the liver functions is proteins and bilirubin synthesis (29). So, decreasing the level of serum protein and increasing of serum bilirubin are an excellent indicator of liver dysfunction, that may be due to inhibition of protein biosynthesis by liver as a result of lead effects due to precipitation of soluble plasma protein that used by lead poison as carrier and alter the activity of high number of enzymes with disruption of protein synthesis in hepatocytes (32). Also decrease in total serum protein may be due to both hepatic and renal damage induced by lead (33).

Also the result are in agreement with result of $(17,34)$ were their result shown decrease in serum total protein levels that reflects major functional changes liver functions. One of the main targets of lead poisoning.

Also increase in serum bilirubin in lead acetate toxicated rats are agood indecator of hepatotoxicity of lead that in agreement with result of (35). The table 1 and figure 4 indicates the important histological and physiological 
effects of Broccoli on the liver because the levels of GPT, GOT, ALK, ACD and TSB decreased significantly in the group that injected with lead acetate and ate Broccoli while the levels of serum TP increased significantly compare to lead acetate treated group, near to their levels in control groups. These results supported by histological examination of liver as shown in figure 4 that revealed the normal cords of hepatocytes, blood sinusoids, and Kupffer cells.

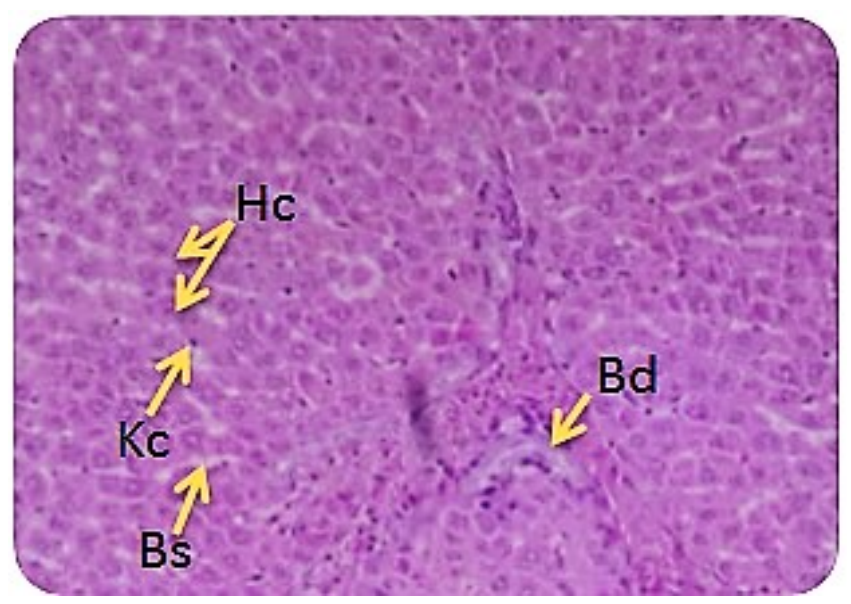

Figure 1: Liver section of group A the control group. The light microscopic images of sections of liver tissue of both A groups showing cords of hepatocytes (HP), blood sinusoids (BS), Kupffer cells (Kc), and portal area note bile $\operatorname{duct}(\mathrm{Bd}) .100 x, \mathrm{H} \& \mathrm{E}$.

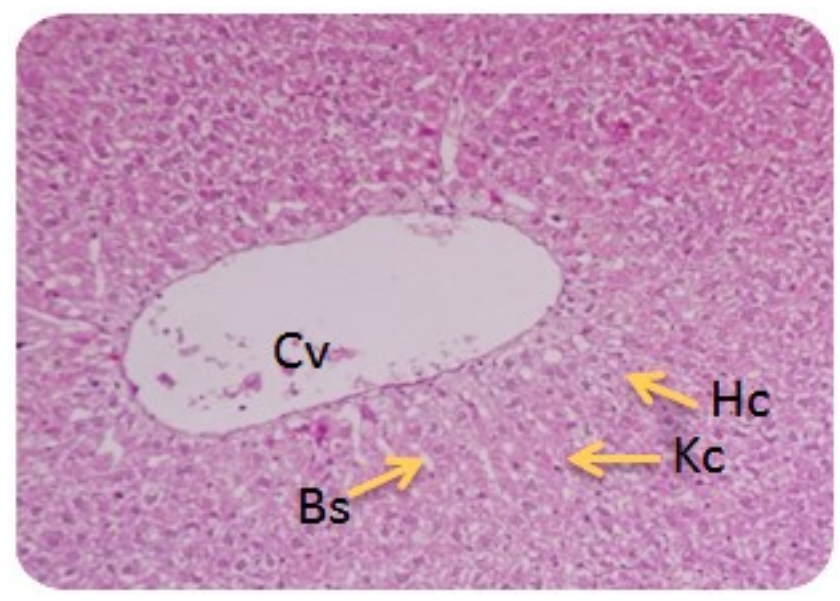

Figure 2: Liver section of group B (that ate Broccoli at $12 \%$ in their standard diet). The light microscopic images of sections of liver tissue of both B groups showing cords of hepatocytes $(\mathrm{Hc})$, central veins $(\mathrm{Cv})$, blood sinusoids (BS), and Kupffer cells (Kc). 40x, H\&E.

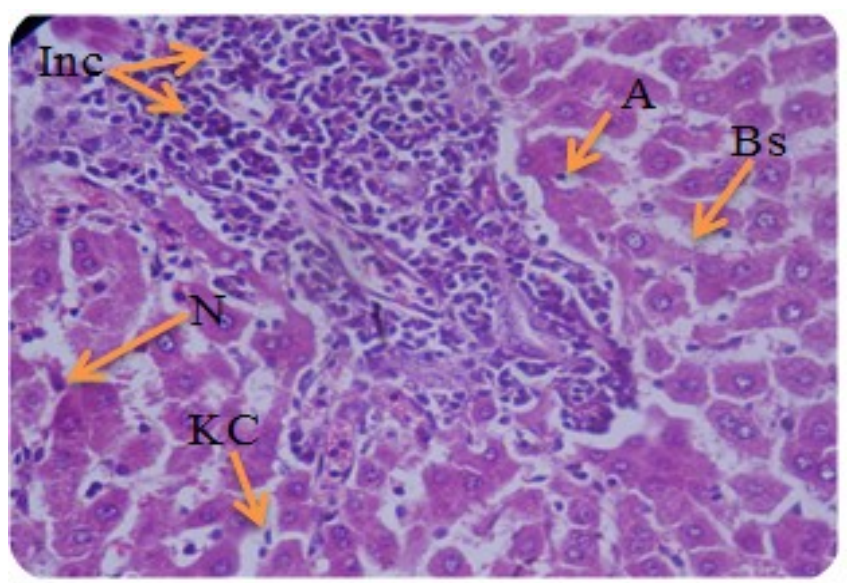

Figure 3: Liver of lead acetate treated rats, that showed great histological changes in the liver tissue of group $\mathrm{C}$ that treated by lead acetate. The figure revealed the presence of infiltration of inflammatory cells (Inc) with sinusoid dilation (Bs), necrosis (N), apoptosis of hepatocyte (A), and Kupffer cells (Kc). 400x, H\&E.

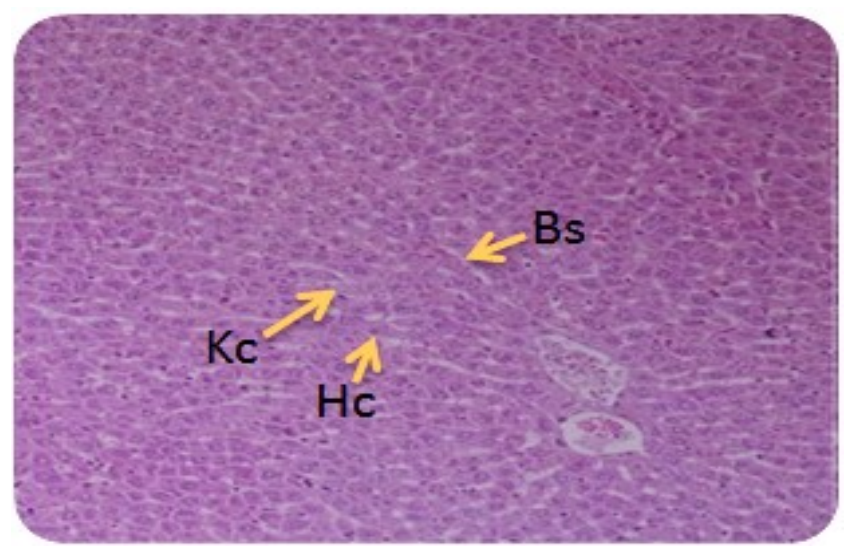

.Figure 4: Liver section of rat treated with lead acetate and Broccoli. Normal cords of hepatocytes (Hc), blood sinusoids (Bs), and Kupffer cells (Kc). 40x, H\&E.

There are several recent studies on the ability of some medical plants like G. kola (36) A. sativum (14), $L$. officinale (37) and L. esculentum (38) to reduce hepatotoxic effect of lead through a hepato-protective role. Protective effects of medicinal plants are varied and depend on the nature of lead exposure (39). Dietary consumption of Brassica vegetables has been associated with a reduction in the incidence of several pathological conditions like cancers and many chronic inflammatory diseases (40). Another recent sudy by (41) they focused on the farmaceutical benefits of Broccoli juices were shown to confer protection to an in vitro model of inflamed human intestinal epithelium based on Caco- 2 cells treated with TNF- $\alpha$ under 
marginal zinc deprivation. Many reports exist in literature about the efficacy of medicinal plant products in ameliorating or reducing the toxicity and accumulation of lead in tissues due to their metal chelating, antioxidant and scavenging properties (42) so may be Broccoli has chelating activities on lead.

Enhancement of the antioxidant capacity of the liver, reduction of hepatocyte injury and lipid peroxidation, improvement of barrier functions and antioxidant activity, decrease oxidative DNA damage in the liver and increased hepatic detoxification and bile production are some of the ways by which broccolis can offer hepatoprotective ability and reduce toxicity of lead. There are some evidences that vitamin $\mathrm{C}$ can inhibit lead uptake at a cellular level as well as lead's cytotoxicity (cellular toxicity). In combination with zinc, glycine and vitamin E, it has been found effective in partially protecting a range of body organs, particularly the liver, from lead-induced damage in animal experiments by acts to protect structures such as cell membranes (43). Broccoli ability to ameliorate hepatotoxicity of lead in rats may be attributed to its high content of vitamins especially $\mathrm{C}$ and $\mathrm{E}$ and minerals. This study indicates the potential use of broccoli as a source of natural antioxidants or nutraceuticals as protective nutrient from lead hepato- toxicity.

\section{Conclusion}

The results of present study showed that the using of lead acetate produces hepatic disorder and the potential use of Broccoli as a source of natural antioxidants or nutraceuticals protects against lead acetate hepatic toxicity.

\section{References}

1. Rumpler J, Schlegel C. Get the lead out: ensuring safe drinking water for our children at school. Environ Am Res Poli Center, 2017;1:35.

2. Sulaf MM. Physiological and histological effects of lead acetate in kidney of Mus Musculus. J Uni Anbar Pure Sci. 2010;4(2):1-7.

3. Sulaf MM. Effect of lead acetate on histological features of liver, skeletal muscle and testis and serum testosterone level of laboratory albino mice Mus musculus. Baghdad Sci J Biol. 2010;7(1):424-430.

4. Flora SJ, Flora G, Saxena G. Environmental occurrence, health effects and management of lead poisoning. In: Cascas SB, Sordo J. editors. Lead chemistry, analytical aspects, environmental impacts and health effects. Netherlands: Elsevier Publication; 2006. p. 158-228.

5. Flora SJ, Saxena G, Gautam P, Kaur P, Gill KD. Response of leadinduced oxidative stress and alterations in biogenic amines in different rat brain regions to combined administration of DMSA and MiADMSA. Chem Biol Interact. 2007;170:209-20.

6. Damek-Poprawa M, Sawicka-Kapusta K. Histopathological changes in the liver, kidneys, and testes of bank voles environmentally exposed to heavy metal emissions from the steelworks and zinc smelter in Poland. Environ Res. 2004;96:72-8.

7. Brennan PA, Kendrick KM, Keverne EB. Neurotransmitter release in the accessory olfactory bulb during and after the formation of an olfactory memory in mice. Neurosci.1995;69:1075-86.
8. Moreira EG, Vassilieff I, Vassilieff VS. Developmental lead exposure: Behavioral alterations in the short and long term. Neurotoxicol Teratol. 2001;23:489-95.

9. Flora SJ, Saxena G, Mehta A. Reversal of lead-induced neuronal apoptosis by chelation treatment in rats: role of reactive oxygen species and intracellular $\mathrm{Ca}^{+2}$. J Pharmacol Exp Ther. 2007;322:10816.

10. Xu J, Ji LD, Xu LH. Lead-induced apoptosis in PC 12 cells: involvement of p53, Bcl-2 family and caspase-3. Toxicol Lett. 2006;166:160-7.

11. Zhai Q, Narbad A, Chen W. Dietary strategies for the treatment of cadmium and lead toxicity. Nutri. 2015;7(1):552-571.

12. Wang X, Ouyang Y, Liu. J, Zhu M, Zhao G, Bao W, Hu FB. Fruit and vegetable consumption and mortality from all causes, cardiovascular disease, and cancer: Systematic review and dose-response metaanalysis of prospective cohort studies. BMJ. 2014;349:4490.

13. Hu D, Huang J, Wang Y, Zhang D, Qu Y. Fruits and vegetables consumption and risk of stroke: A meta-analysis of prospective cohort studies. Stroke. 2014;45:1613-1619.

14. Nwokocha CR, Owu DU, Nwokocha MI, Ufearo CS, Iwuala MO. Comparative study on the hepatoprotection to heavy metals of Zingiber officinale. Pharmacol Res. 2012;4:208-13.

15. Merriam-Webster's Collegiate Dictionary. Broccoli. 2014; 11th edition.

16. Palak A, Soni K, Thakur A, Kohli K. Broccoli: An insight into formulation and patentability aspects, review article. Drug Desi: Open Access. 2016;5(3):1-12.

17. Sulaf MM. Effect of Broccoli (Brassica oleracea) on some physiological variables and reproductive system on lead acetate exposed adult male albino (Rattus rattus) [master's thesis]. Tikrit: Tikrit University; 2015.

18. Boeing H, Bechthold A, Bub A, Ellinger S, Haller D, Kroke A, Leschik-Bonnet E, Muller MJ, Oberritter H, Schulze M. Critical review vegetables and fruit in the prevention of chronic diseases. Eur J Nutr. 2012;51:637-663.

19. USDA National Nutrient Database for Standard Reference Release 28. Broccoli, raw. Basic Report: 2017; 11090.

20. Wagner AE, Terschluesen AM, Rimbach G. Health promoting effects of brassica-derived phytochemicals: From chemopreventive and antiinflammatory activities to epigenetic regulation. Oxid Med Cell Longev. 2013;9:964539.

21. Jahangir M, Kim HK, Choi YH, Verpoorte R. Health-affecting compounds in Brassicaceae. Compr Rev Food Sci Food Saf. 2009;8:31-43.

22. Lim S, Hwang J. Antioxidant and Anti-inflammatory activities of Broccoli florets in LPS-stimulated RAW 264.7 Cells. Prev Nutr Food Sci. 2014;19(2):89-97.

23. Subramanian P, Sivabalan S, Menon VP, Vasudevan K. Influence of chronic zinc supplementation on biochemical variables and circadian rhythms in wistar rats. J Nutr Res. 2000;20:413-425.

24. Thornton I, Rautiu R, Brush S. Lead the facts, prepared by IC consultants Ltd London, UK; 2001. 177p.

25. Tietz NW. Text book of clinical chemistry, $3^{\text {rd }}$ ed. Philadelphia: W.B. Saunders Company; 1999. 477-530 p.

26. Suvarna SK, Layton C, Bancroft JD. Bancroft's Theory and practice of histological techniques. $11^{\text {th }}$ ed. New York: Churchill Living Stone; 2013.

27. Mudipall A. Lead hepatoto- xicity and potential health effects. Indian J Med Res. 2007;126:518-27.

28. Patrick LND. lead toxicity part II: The role of free radical damage and the use of antioxidant in the pathology and treatment of lead toxicity (Review). Altern Med Rev. 2006;11:114-27.

29. Guyton AC, Hall JE. Textbook of Medical Physiology. $11^{\text {th }}$ edition. New York: W.B. Saunders; 2011.

30. Ibrahim NM, Eweis EA, El-Beltagi HS, Abdel-Mobdy YE. Effect of lead acetate toxicity on experimental male albino rat. Asian Pacific $\mathrm{J}$ Trop Biomed. 2012;2(1):41-46. 
31. Abdou H, Newairy A. Hepatic and reproductive toxicity of lead in female rats and attenuation by flaxseed lignans. Med Res Inst. 2006;27(4):295-302.

32. Lowry JA, Pearce E, Gaedigk A, Venneman M, Talib N, Shaw P, Leeder JS, Kearns GL. Lead and its effects on cytochromes P450. J Drug Metab Toxicol. 2012;5:4.

33. Yuan G, Dai S, Yin Z, Lu H, Jia R, Xu J. Sub-chronic lead and cadmium co-induce apoptosis protein expression in liver and kidney of rats. Int J Clin Exp Pathol. 2014;7(6):29052914.

34. Pachathundikandi SK, Varghese ET. Blood zinc protop- orphyrin, serum total protein, and total cholesterol levels in automobile workshop workers in relation to lead toxicity: Our experience. Indian J Clin Biochem, 2006;21(2):114-117.

35. Mohamed M, Ugarte-Torres A, Groshaus H, Rioux K, Yarema M. Lead poisoning from a ceramic jug presenting as recurrent abdominal pain and jaundice. ACG Case Rep J. 2016;3(2):141-143.

36. Nwokocha CR, Owu DU, Ufearo CS, Iwuala MO. Comparative study on the efficacy of Garcinia kola in reducing some heavy metal accumulation in liver of Wistar rats. J Ethnopharmacol. 2011;35:48891.

37. Nwokocha CR, Nwokocha MI, Aneto I, Obi J, Udekweleze DC, Olatunde B. Comparative analysis on the effect of Lycopersicon esculenttum (tomato) in reducing cadmium, mercury and lead accumulation in liver. Food Chem Toxicol. 2012;50:2070-3.
38. Nwokocha CR, Owu DU, Nwokocha MI, Ufearo CS, Iwuala MO. Comparative study on the efficacy of Allium sativum (garlic) in reducing some heavy metal accumulation in liver of wistar rats. Food Chem Toxicol. 2012;50:222-6.

39. Nwokocha C, Younger-Coleman N, Nwokocha M, Owu D, Iwuala M. A comparative study of the effect of some nutritional medicinal plants effect on lead accumulation in the liver following different modes of administration. Pharmacognosy Res. 2014;6(4):306-311.

40. Medina S, Domínguez-Perles R, Moreno DA, García-Viguera C, Ferreres F, Gil JI, Gil-Izquierdo Á. The intake of broccoli modulates the inflammatory and vascular prostanoids but not the oxidative stress-related isoprostanes in healthy humans. Food Chem. 2015;173:1187-119.

41. Ferruzza S, Natella F, Ranaldi G, Murgia C, Rossi C, Trošt K, Baima S. Nutraceutical improvement increases the protective activity of broccoli sprout juice in a human intestinal cell model of gut inflammation. Pharmaceut. 2016;9(3):48.

42. Tito A, Carola A, Bimonte M, Barbulova A, Arciello S, de Laurentiis F. A tomato stem cell extract, containing antioxidant compounds and metal chelating factors, protects skin cells from heavy metal-induced damages. Int J Cosmet Sci. 2011;33:543-52.

43. Roberts A, Sweeny C. Fact sheet: Nutrients that reduce lead poisoning. Lead Action News. 2010;10(2): 3-4. 